\title{
Outcome of superficial squamous cell carcinoma of the esophagus. A clinicopathological study ${ }^{1}$
}

\author{
Maria Aparecida Coelho de Arruda Henry ${ }^{\mathrm{I}}$, Mauro Masson Lerco" ${ }^{\mathrm{II}}$, Luiz Eduardo Naresse ${ }^{\mathrm{III}}$, Eduardo Crema ${ }^{\mathrm{IV}}$, Maria Aparecida \\ Marchesan Rodrigues $\mathrm{v}$ \\ ${ }^{I} \mathrm{PhD}$, Full Professor, Department of Surgery, Gastroenterology Surgery Division, Botucatu Medical School, UNESP, Botucatu-SP, Brazil. \\ Conception and design of the study, acquisition and interpretation of data, revising and approving the final version. \\ IIPhD, Assistant Professor, Department of Surgery, Gastroenterology Surgery Division, Botucatu Medical School, UNESP, Botucatu-SP, Brazil. \\ Acquisition and interpretation of data. \\ IIIPhD, Associate Professor, Department of Surgery, Gastroenterology Surgery Division, Botucatu Medical School, UNESP, Botucatu-SP, Brazil. \\ Acquisition and interpretation of data. \\ ${ }^{\text {IV }} \mathrm{PhD}$, Full Professor, Department of Surgery, Gastroenterology Surgery Division, Faculty of Medicine, Triangulo Mineiro University, MG-Brazil. \\ Acquisition and interpretation of data. \\ ${ }^{v} \mathrm{PhD}$, Full Professor, Department of Pathology, Investigative Pathology Division, Botucatu Medical School, UNESP, Botucatu-SP, Brazil. Interpretation \\ of data, drafting the article, revising and approving the final version.
}

\section{ABSTRACT}

PURPOSE: To analyze the clinicopathological features and outcome of patients with pathologically proven superficial squamous cell carcinoma of the esophagus.

METHODS: A total of 234 consecutive cases of esophageal carcinoma in a 15-year period were reviewed.

RESULTS: Superficial esophageal cancer was found in five patients (2.1\%). They were four men and one woman and the mean age was 52.5 years. Smoking and alcohol were the main risk factors. Achalasia due to Chagas disease occurred in one patient and a second primary tumor developed in the larynx in another patient. Four patients underwent esophagectomy and one patient received chemoradiotherapy. The histopathologic diagnosis was of squamous cell carcinoma in all cases. Intramucosal tumor (Tis) was identified in three cases and superficially invasive carcinoma in two cases. Four patients are free of disease with survival times of two, four, six and nine years. The patient who developed laryngeal cancer died six years after esophagectomy.

CONCLUSION: Long-term survival in patients with esophageal cancer is related to early diagnosis. Therefore, a less aggressive surgical approach, such as endoscopic resection, may be a good option for these patients, if depth of tumor invasion can be accurately predicted by the new imaging tools.

Key words: Carcinoma, Squamous Cell. Esophageal Neoplasms. Early Detection of Cancer. 


\section{Introduction}

The outcome of patients with esophageal cancer remains dismal with 5-year survival about 10\% despite advances in diagnosis, staging and therapeutic procedures ${ }^{1-3}$. This high mortality rate has been mainly related to late diagnosis ${ }^{1,2,4}$. In developing countries more than $90 \%$ of esophageal cancers are at late stage when the diagnosis is established, with only a minority of patients elected for curative surgery ${ }^{4}$.

Therefore, the best strategy to improve the chances of long-term survival is the identification of lesions at early stage ${ }^{5,6}$. However, detection of early esophageal cancer is very unusual even in European countries and North America, where expensive techniques are available ${ }^{7-9}$.

Endoscopically, it is often difficult to identify early superficial neoplastic lesions in the esophageal mucosa by conventional endoscopy, but application of iodine has been useful to enhance the detection of discrete neoplastic lesions ${ }^{10-13}$. In addition, new types of endoscopic techniques, including magnifying endoscopy, narrow-band imaging (NBI) and endocytoscopy are promising tools for detection of neoplastic lesions at early stage $e^{6,14-16}$.

There are few reports on the prevalence and pathobiologic characteristics of early esophageal cancer in developing countries like Brazil, where this tumor is the fourth leading cause of cancerrelated mortality in $\operatorname{men}^{17}$ and squamous cell carcinoma is the most common histological type, accounting for more than $90 \%$ of cases ${ }^{17}$.

The aim of this retrospective study was to analyze the clinicopathological features and outcome of superficial esophageal squamous cell carcinoma in a cohort of patients from southern Brazil.

\section{Methods}

A total of 234 consecutive patients with esophageal carcinoma were referred to Botucatu University Hospital-UNESP, a Medical Center at the Midwestern São Paulo State, Brazil, in a 15-year period between January 1996 and January 2010. Among them, five patients $(2.1 \%)$ were retrospectively enrolled in the study due to the pathological diagnosis of superficial esophageal cancer, which was defined as a carcinoma limited within the mucosa or submucosa irrespective of lymph node metastasis $^{3}$. Patients' medical records were reviewed for age, gender, endoscopic tumor appearance (flat or nodular), pathologic tumor characteristics $(\mathrm{pT})$, lymph node metastasis $(\mathrm{pN})$ and clinical outcome. In all resected surgical specimens the pathologic features such as tumor size, presence or absence of lymph node metastasis and lymphovascular invasion were assessed according to previously published criteria ${ }^{18}$. Tumor in situ was characterized by an intramucosal tumor (Tis). Superficially invasive carcinoma was defined as a tumor infiltrating the mucosa or submucosa without invasion of the muscularis propria (T1). Depth of tumor invasion was considered as T1a: Tumor invading lamina propria or muscularis mucosae. T1b: Tumor invasion of the submucosa. On the histopathological analysis tumor differentiation was graded on Hematoxylin and Eosin stained slides, based on the predominant tumor differentiation present in more than $75 \%$ of the tumor component. The study was approved by the local Hospital Ethical Committee

\section{Results}

The clinicopathological features of the patients with superficial esophageal cancer are summarized on Table 1.

TABLE 1 - Clinicopathological features of superficial esophageal cancer.

\begin{tabular}{cc}
\hline Variable & $\mathbf{n}$ \\
\hline Gender & \\
Male & 4 \\
Female & 1 \\
\hline Age & \\
\hline The youngest & 45 years \\
The oldest & 58 years \\
Mean & $52.5 \pm 5.4$ years \\
\hline
\end{tabular}

\begin{tabular}{cl}
\hline Risk Factors & \\
\hline Alcoholism + Smoking & 2 \\
Alcoholism + Smoking + Achalasia & 1 \\
Alcoholism + Smoking + Hot beverages & 1 \\
Family history of cancer & 1 \\
\hline Tumor Location & 0 \\
\hline Upper third & 2 \\
Middle third & 3 \\
Lower third &
\end{tabular}

Four patients were male and one was female, aged from 45 to 58 years (mean: $52.5 \pm 5.4$ years). They were all leukodermic patients. They reported slight dysphagia, ranging from 3 to 5 months (mean: $4.2 \pm 0.9$ months). Weight loss was also reported and ranged from $4 \%$ to $16 \%$ (mean: $7.5 \pm 5.9$ ).

Concerning risk factors, the four male patients had 
a history of alcoholism and smoking for 30 years. One of them had achalasia due to Chagas disease with esophageal and colonic involvement. The female patient denied having the previously cited history, but her father had died from brain cancer. All patients were in good clinical and nutritional conditions, with body mass index within normal range (mean: $23.7 \pm 0.2 \mathrm{~kg} / \mathrm{m}^{2}$ ).

Endoscopy showed flat or ulcerated lesions in the middle third of the esophagus in two patients and in the distal region in another three patients. Biopsies of the lesions revealed squamous cell carcinoma in all patients. Endoscopy failed to identify the neoplastic lesion in the patient with advanced megasophagus.

After verifying normal results for abdominal and thoracic CT scans as well as for cardiac and pulmonary assessment, three patients underwent subtotal transhiatal esophagectomy followed by cervical gastroesophageal anastomosis, jejunostomy and pyroplasty. One patient was submitted to video-assisted surgery and another patient denied surgical treatment and was referred to chemoradiotherapy. The patient with advanced megaesophagus was submitted to transhiatal esophagectomy aiming at treating the esophagopathy. The neoplastic lesion was incidentally found during pathological examination of the surgical specimen.

Surgical resection of the tumor was complete in the four patients submitted to esophagectomy. The pathological findings of surgical specimens are shown on Table 2.

On macroscopic examination, a slightly elevated lesion was found in one case, a flat mucosal appearance was observed in two cases, being one case with irregular and confluent erosions. An ulcerated lesion was observed in one case and an incidental mass was found on macroscopic examination in the megaesophagus from the patient with Chagas disease.

Tumor size ranged from $1.0 \mathrm{~cm}$ to $2.5 \mathrm{~cm}$. Histologically, all tumors showed features of conventional squamous cell carcinoma well-differentiated in four cases and moderatelydifferentiated in one case (Figure 1).

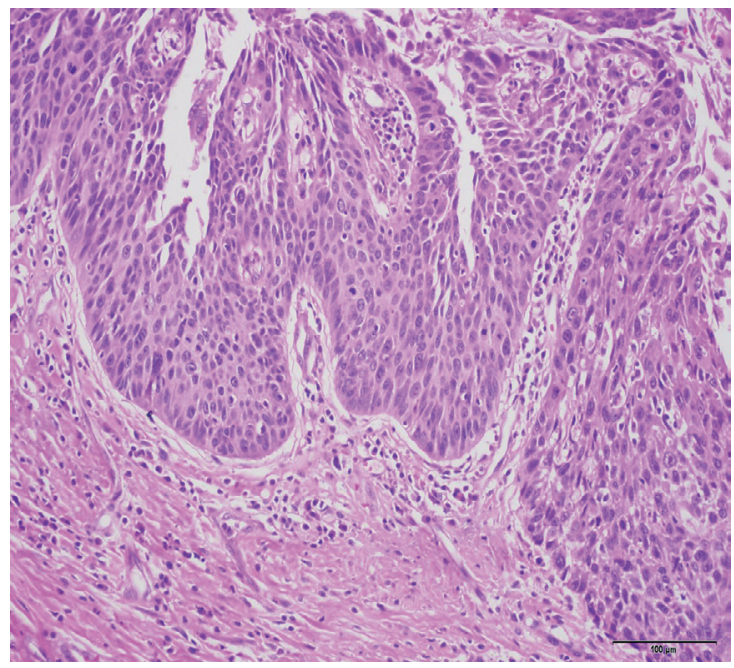

FIGURE 1 - Histologic features of intramucosal squamous cell carcinoma of the esophagus (H\&E stain, 200x).

The depth of tumor invasion was intramucosal in three cases (Tis) and submucosal in the other two cases, T1a in one case and $\mathrm{T} 1 \mathrm{~b}$ in another case. Lymphovascular tumor invasion and nodal metastasis were not identified in any case. There were no post-operative deaths. One patient developed cervical fistula, followed by stenosis, which evolved favorably after endoscopic dilatation. Pulmonary complications such as pleural effusion and pneumonia occured in two patients and went into total remission

TABLE 2 - Histopathological findings and outcome of superficial esophageal cancer.

\begin{tabular}{|c|c|c|c|c|c|c|c|}
\hline Case & $\begin{array}{c}\text { Age/ } \\
\text { Gender }\end{array}$ & $\begin{array}{c}\text { Procedure/ Tumor } \\
\text { Location }\end{array}$ & $\begin{array}{c}\text { Tumor Size } \\
\text { \& Type }\end{array}$ & Depth Invasion & Histologic Grade & Tumor Stage & Outcome \\
\hline 1 & $53 / \mathrm{F}$ & $\begin{array}{l}\text { Surgery } \\
\text { Middle }\end{array}$ & $\begin{array}{c}15 \mathrm{~mm} \\
\text { Flat }\end{array}$ & $\mathrm{Im}$ & Well dif & Tis & $\begin{array}{l}\text { Alive } \\
9 \mathrm{Yr}\end{array}$ \\
\hline 2 & $45 / \mathrm{M}$ & $\begin{array}{l}\text { Surgery } \\
\text { Middle }\end{array}$ & $\begin{array}{l}17 \mathrm{~mm} \\
\text { Flat }\end{array}$ & $\mathrm{Im}$ & Well dif & Tis & $\begin{array}{c}\text { Dead } \\
\text { Laryns Ca }\end{array}$ \\
\hline 3 & $58 / \mathrm{M}$ & $\begin{array}{l}\text { Surgery } \\
\text { Distal }\end{array}$ & $\begin{array}{l}15 \mathrm{~mm} \\
\text { Ulcer }\end{array}$ & $\mathrm{Sm}$ & Mod dif & $\mathrm{T} 1 \mathrm{a}$ & $\begin{array}{l}\text { Alive } \\
6 \mathrm{Yr}\end{array}$ \\
\hline 4 & $54 / \mathrm{M}$ & $\begin{array}{l}\text { Surgery } \\
\text { Distal }\end{array}$ & $\begin{array}{c}25 \mathrm{~mm} \\
\text { Elev }\end{array}$ & $\mathrm{Sm}$ & Well dif & $\mathrm{T} 1 \mathrm{~b}$ & $\begin{array}{c}\text { Alive } \\
\text { 2yr Chagas }\end{array}$ \\
\hline 5 & $52 / \mathrm{M}$ & $\begin{array}{c}\text { Chemoradio } \\
\text { Distal }\end{array}$ & $\begin{array}{l}10 \mathrm{~mm} \\
\text { Elev }\end{array}$ & $\mathrm{Im}$ & Well dif & Tis & $\begin{array}{l}\text { Alive } \\
4 y r\end{array}$ \\
\hline
\end{tabular}

$\mathrm{SCC}=$ Squamous Cell Carcinoma $\mathrm{Im}=$ Intramucosal tumor (in situ) $\mathrm{Sm}=$ Submucosal tumor

Tis $=$ Carcinoma in situ $\quad \mathrm{T} 1 \mathrm{a}=$ Tumor invades muscularis mucosa $\mathrm{T} 1 \mathrm{~b}=$ Tumor invades submucosa 
following antibiotic therapy and pleural drainage.

Among all patients, four of them are alive with survival times of two, four, six and nine years, in good clinical conditions and free of the disease. One patient developed a second primary tumor in the larynx and died six years after surgery.

\section{Discussion}

In this study, we analyzed the clinicopathological features and outcome of five patients from southern Brazil with pathologically proven superficial esophageal squamous cell carcinoma surgically treated to add more information on the pathobiologic characteristics of early esophageal cancer and to contribute to therapeutic decision-making.

We have found that only $2.1 \%$ of all patients surgically treated for esophageal carcinoma $(n=234)$ presented the lesion at early stage. The reported incidence of superficial esophageal carcinoma varies from 10-20\% of all resected carcinomas in Japan ${ }^{19}$ whereas it is much less frequent in European countries and North America ${ }^{1,3,7}$. This wide range in incidence can be attributed in part to the pathological criteria used for the diagnosis of esophageal carcinoma and to the high number of endoscopies performed in asymptomatic individuals associated to the routine use of iodine staining (Lugol) which enhances the presence and extent of small malignant lesions in the esophageal mucosa, even those not visible radiologically and endoscopically ${ }^{10-13}$.

Regarding the pathological criteria of squamous dysplasia and squamous cell carcinoma, the views of Western and Japanese pathologists have significant differences. Japanese pathologists report the diagnosis of squamous cell carcinoma in lesions, in which, Western pathologists would consider as dysplasia ${ }^{20-22}$.

Concerning risk factors, our data showed that tobacco smoke and alcohol were the main risk factors for esophageal cancer. A second primary tumor developed in the larynx in one patient and achalasia due to Chagas disease occurred in another patient. In this patient the neoplastic lesion was found only after esophageal resection performed for treatment the advanced megaesophagus. It was not detected preoperatively, probably due to lack of adequate preparation for endoscopy. Although our series of cases is very limited, it reproduces the well known risk factors for esophageal squamous cell carcinoma ${ }^{1,3,6}$.

In our study, three patients had intramucosal tumor (Tis), invasion of the muscularis mucosae (T1a) was found in one case and of the upper third of the submucosa (T1b) in another case. Lymphovascular tumor invasion and nodal metastasis were not identified in any case. These pathological findings associated with the small tumor size, which was less than $3 \mathrm{~cm}$ in all cases, may explain the long-term survival achieved after curative surgical resection in our patients. Only one patient died six years after esophagectomy due to a second primary tumor in the larynx.

Treatment of early esophageal cancer may be performed using several procedures ${ }^{19,23-25}$. Esophagectomy has been considered the most radical and associated with significant morbidity and mortality, particularly in elderly patients and/or those with concurrent illness. Less invasive surgical procedures, such as endoscopic mucosal resection has been advised for these patients ${ }^{19,23}$. In our study the patients with superficial esophageal cancer were referred to subtotal esophagectomy, as preoperative staging with endoscopic ultrassonography was not available, and without it, tumor extention to superficial esophageal wall could not be assessed.

Endoscopic procedures, such as endoscopic mucosal resection and endoscopic submucosal dissection have become possible choices for the treatment of esophageal cancer at early stage $^{19,23}$. A judicious use of these procedures must be considered and patients should only be referred to them when the lesions are small and shorter than $2 \mathrm{~cm}$, with circumferential involvement less than $50 \%$, limited to the mucosa and without lymphatic or vascular invasion ${ }^{24}$.

Other endoscopic treatment option for superficial esophageal cancer refers to ablation using radiofrequency. This technique was used by Bergman et $a l .{ }^{25}$ in patients with intraepithelial neoplasia with $97 \%$ complete response. According to Galey et al. ${ }^{24}$, endoscopic resection of the mucosa has advantages over ablation using radiofrequency, as it allows the preservation of the specimens for histopathological studies.

In our study, three out of the four operated patients are free of the disease four, six and nine years, in good clinical conditions and receiving annual follow-up care. One of the operated patients relapsed to distilled spirits drinking, as he used to do in the preoperative period. As a consequence, laryngeal cancer developed, possibly because of the increase in the speed of alcohol absorption, as a result of the anatomical change induced by esophagectomy. The patient died six years after surgery. The patient who underwent chemoradiotherapy has been in good clinical conditions for four years after treatment.

\section{Conclusions}

Surgical resection provides long-term survival for patients with esophageal cancer at early stage. Less invasive surgical procedures, such as limited resections with endoscopic 
resection may be the best option for these patients, if depth of tumor invasion can be accurately predicted by the new imaging tools. Therefore, early small tumors require surgeons to identify superficial lesions exclusively, before the decision between surgical and endoscopic procedures.

\section{References}

1. Enzinger PC, Mayer RJ. Esophageal cancer. N Engl J Med. 2003;349:2241-52.

2. CRUK 2009 'Cancer survival rates for patients diagnosed 19961999.' Survival statistics for the most common cancers. Cited 23/05/2011. Available from http: //info.cancerresearchuk.org/ cancerstats/survival/latestrates/

3. Montgomery E, Field JK, Boffetta P, Daigo Y, Shimizu M, Shimoda T. Squamous cell carcinoma of the oesophagus. In: Bosman FT, Carneiro F, Hruban RH, Theise ND (Eds): WHO Classification of Tumors of the Digestive System. IARC: Lyon; 2010.

4. Abdullah M, Karim AA, Goh KL. Late presentation of esophageal cancer: observations in a multiracial South-East Asian population. J Dig Dis. 2010;11:28-33.

5. Chen LQ, Hu CY, Ghadirian P, Duranceau A. Early detection of esophageal squamous cell carcinoma and its efects on therapy: an overview. Dis Esophagus. 1999;12:161-7.

6. Lopes AB, Fagundes RB. Esophageal squamous cell carcinoma precursor lesions and early diagnosis. World J Gastrointest Endosc. 2012;16;4:9-16.

7. Froelicher P, Miller G. The European experience with esophageal cancer limited to the mucosa and submucosa. Gastrointest Endosc. 1986;32:88-90.

8. Schlansky B, Dimarino A J, Loren D, Infantolino A, Kowalski T, Cohen S. A survey of oesophageal cancer: pathology, stage and clinical presentation. Aliment Pharmacol Ther. 2006;23:587-93.

9. Dubuc J, Legoux JL, Winnock M, Seyrig JA, Barbier JP, Barrioz, T, Laugier R, Boulay G, Grasset D, Sautereau D, Grigoresco D, Butel J, Scoazec GY, Ponchon T, and the Société Française d'Endoscopie Digestive. Endoscopic screening for esophageal squamous-cell carcinoma in highrisk patients: a prospective study conducted in 62 French endoscopy centers. Endoscopy. 2006;38:690-5.

10. Dawsey SM, Fleischer DE, Wang GQ, Zhou B, Kidwell GA, Lu N, Lewin KJ, Roth MJ, Tio TL, Taylor PR. Mucosal iodine staining improves endoscopic visualization of squamous dysplasia and squamous cell carcinoma of the esophagus in Linxian, China. Cancer. 1998;83:220-31.

11. Freitag CP, Barros SG, Kruel CD, Putten ACK, Dietz J, Gruber AC, Diehl AS, Meurer L, Breyer HP, Wolf F, Vidal R, Arruda CA, Luz LP, Fagundes RB, Proela JC. Esophageal dysplasias are detected by endoscopy with Lugol in patients at risk for squamous cell carcinoma in southern Brazil. Dis Esophagus. 1999;12:191-5.

12. Fagundes RB, de Barros SG, Pütten AC, Mello ES, Wagner M, Bassi LAP, Bombassaro MA, Gobbi D, Souto EB. Occult dysplasia is disclosed by Lugol chromoendoscopy in alcoholics at high risk for squamous cell carcinoma of the esophagus. Endoscopy. 1999;31:281-5.

13. Hashimoto $\mathrm{CL}$, Iriya $\mathrm{K}$, Baba ER, Navarro-Rodrigues $\mathrm{T}$, Zerbini MC, Eisig JN, Barbuti R, Chinzon D, Moraes-Filho JPP. Lugol's dye spray chromoendoscopy establishes early diagnosis of esophageal cancer in patients with primary head and neck cancer. Am J Gastroenterol. 2005;100:275-82.

14. Yoshida Y, Goda K, Tajiri H, Urashima M, Yoshimura N, Kato T. Assessment of novel endoscopic techniques for visualizing superficial esophageal squamous cell carcinoma: autofluorescence and narrow-band imaging. Dis Esophagus. 2009;22:439-46.

15. Takenaka R, Kawahara Y, Okada H, Hori K, Inoue M, Kawano S, Tanioka D, Tsuzuki T, Uemura M, Ohara N, Tominaga S, Onoda T,
Yamamoto K. Narrow-band imaging provides reliable screening for esophageal malignancy in patients with head and neck cancers. Am J Gastroenterol. 2009;104:2942-8.

16. Ishihara R, Takeuchi Y, Chatani R, Kider T, Inoue T, Hanaoka N, Yamamoto S, Higashino K, Uedo N, Ishi H, Tatsuta M, Tomita Y, Ishiguro S. Prospective evaluation of narrowband imaging endoscopy for screening of esophageal squamous mucosal highgrade neoplasia in experienced and less experienced endoscopists. Dis Esophagus. 2010;23:480-6.

17. Instituto Nacional do Câncer. Câncer no Brasil. Dados dos registros de base populacional. Disponível em http://www.inca.gov.br/ regpop/2012.

18. Edge SB, Byrd DR, Compton CC, Fritz Ag, Greene FL, Trotti A. AJCC Cancer staging manual. 7th ed. New York: Springer-Verlag; 2010.

19. Fujita H, Sueyashi S, Yamana H, Shinozaki K, Toh U, Tanaka Y, Mine T, Kubota M, Shirouzu K, Toyonaga A, Harada H, Ban S, Watanbe M, Toda Y, Tabuchi E, Hayabuchi N, Inutsuka H. Optimum treatment strategy for superficial esophageal cancer: Endoscopic mucosal resection versus radical esophagectomy. World J Surg. 2001;25:424-31.

20. Schlemper RJ, Dawsey SM, Itabashi M, Iwashita A, Kato Y, Koike M, Lewin KJ, Riddell RH, Shimoda T, Sipponen P, Stolte M, Watanabe $\mathrm{H}$. Differences in diagnostic criteria for esophageal squamous cell carcinoma between Japanese and western pathologists. Cancer. 2000;88:996-1006.

21. Takubo K, Aida J, Sawabe M, Kurosumi M, Arima M, Fujishiro M, Arai T. Early squamous cell carcinoma of the oesophagus: the Japanese viewpoint. Histopathology. 2007;51(6):733-42.

22. Shimizu M, Nagata K, Yamaguchi H, Kita H. Squamous intraepithelial neoplasia of the esophagus: past, present, and future. J Gastroenterol. 2009;44:103-12.

23. Shimizu Y, Tsukagoshi H, Fujita M, Hosokawa M, Kato M, Asaka M. Long-term outcome after endoscopic mucosal resection in patients with esophageal squamous cell carcinoma invading the muscularis mucosae or deeper. Gastrointest Endosc. 2002;56:38790.

24. Galey KM, Wilshire CL, Watson TJ, Schneider MD, Kaul V, Jones CE, Little VR, Ullah A, Peters JH. Endoscopic management of early esophageal neoplasia: an emerging standard. J. Gastrointest Surg. 2011;15:1728-35.

25. Bergman JJGHM, Zhang YM, He S, Weusten B, Xue L, Fleischer DE, Lu N, Dawsey SM, Wang QG. Outcomes from a prospective trial of endoscopic radiofrequency ablation of early squamous cell neoplasia of the esophagus. Gastrointest Endosc. 2011;74:1180-90.

\section{Correspondence:}

Maria Aparecida Coelho de Arruda Henry

Departamento de Cirurgia e Ortopedia

Faculdade de Medicina de Botucatu-UNESP

Distrito de Rubião Junior

18618-970 Botucatu - SP Brasil

Tel.: (55 14)3811-6238

Fax: (55 14)3811-2348

rhenry@ibb.unesp.br

Received: January 23, 2013

Review: March 21, 2013

Accepted: April 22, 2013

Conflict of interest: none

Financial source: none

${ }^{1}$ Research performed at Department of Surgery, Gastroenterology Surgery Division, Department of Pathology, Botucatu Medical School, Sao Paulo State University (UNESP), Botucatu-SP, Brazil. 
Henry MACA et al. 